\title{
About the new model of institutions of sustainable innovative development in Russia
}

\author{
Alsu Akhmetshina ${ }^{1}$ [0000-0001-8317-6500] \\ ${ }^{1}$ Kazan Volga Region Federal University, Kazan, 420008, Russia
}

\begin{abstract}
The article analyzes the activities of innovative development institutions in Russia. The key problems that hinder innovation processes and the development of innovation infrastructure are identified. The tasks and main areas of activity of large innovative development institutions are defined. Key performance indicators of development institutions are proposed, as well as a set of measures that ensure the effectiveness of their functioning in modern Russian.

Keywords: development institutions, sustainable development, innovation processes, project financing, key performance indicators.
\end{abstract}

\section{Introduction}

The issues of digitalization and automation of industry are a priority for the strategic development of meso-and macro-systems. At the global level, the pace of digitalization and increasing the level of innovation in Russia should be characterized as rather slow. This is primarily due to the need for high investment in the development of the information and communication environment of industrial enterprises, high transaction costs, and a number of other factors. Development institutions are one of the state policy instruments that contribute to the development of innovative infrastructure in Russia. The main task of innovation development institutes is to form a comprehensive infrastructure to support applied innovations, to provide technological platforms for the development of innovative business.

The order of the Government of the Russian Federation of February 5, 2021 [1] approved the list of innovative development institutions in Russia. The list reflects the following main development institutions:

1. Joint-Stock Company «DOM.RF» (Ministry of Construction, Housing and Utilities of the Russian Federation);

2. Joint-Stock Company «Corporation for the Development of the Far East and the Arctic» (Ministry of the Russian Federation for the Development of the Far East and the Arctic);

3. Joint-Stock Company «Rosinfocominvest» (The Russian Investment Fund for information and communication technologies) (Ministry of Digital Development, Communications and Mass Media of the Russian Federation);

4. Joint-Stock Company «Rusnano» (Ministry of Economic Development of the Russian Federation); 
5. Joint-Stock Company «Russian Venture Company» (RVC) (Ministry of Economic Development of the Russian Federation);

6. Joint-Stock Company «Federal Corporation for the Development of Small and Medium Enterprises «(Ministry of Economic Development of the Russian Federation);

7. State Development Corporation «Bank for Development and Foreign Economic Affairs» (VEB.RF) (Ministry of Economic Development of the Russian Federation);

8. Non-profit Organization «Foundation for the Development of the Center for Elaboration and Commercialization of New Technologies» (Skolkovo) (Ministry of Finance of the Russian Federation);

9. Russian Fund for the Development of Information Technologies (Ministry of Finance of the Russian Federation);

10. Federal State Budgetary Institution «Foundation for Assistance to the Development of Small Forms of Enterprises in the Scientific and Technical Sphere»(Ministry of Economic Development of the Russian Federation);

11. Fund for Infrastructure and Educational Programs (Ministry of Science and Higher Education of the Russian Federation).

Special attention is paid to the issues of evaluating the effectiveness of Russian development institutions, identifying their strengths and weaknesses in comparison with similar development institutions operating in several of the world's leading innovation ecosystems and participating in improving the financial results of the real sector of the economy in the report presented by the Financial Research Institute [2]. Scientists under the editorship of Rykova I. N. also prepared recommendations for clarifying regulatory legal and other acts. They regulate the activities of Russian development institutions in order to increase their effectiveness and contribution to the Russian economy. The analysis from the point of view of differences in the business models of the Foundation for the Promotion of Innovation, Russian Venture Company, Rusnano, Skolkovo, and their impact on the development of innovations is carried out in the work of T. V. Tishchenko [3]. The scientific works of A. I. Shinkevich, M. V. Shinkevich, and S. S. Kudryavtseva pay special attention to the modeling of innovation processes and the identification of key institutional factors at the micro, meso, and macro levels that contribute to the development of innovations [4-6]. Milkina I. V. [7] in her works reviews the most effectively functioning development institutions at the federal level, which is accompanied by data on the results of their activities in the regions and municipalities of Russia. The analysis of the main factors and conditions that determine the main directions of investment in priority projects is presented in the scientific works of Kostyukhin Yu.Yu., Sidorova E. Yu. [8-10]. At the same time, we consider it necessary to identify the main problems that hinder the effectiveness of development institutions, and to determine key performance indicators in order to assess the effectiveness of innovation development institutions in the Russian environment.

\section{Materials and methods}

The theoretical basis of the study was the work of scientists of a theoretical and practical nature, studying the effectiveness of the institutions of innovative development. The methodological basis of the study was based on general scientific approaches to research: system analysis, description, comparison, methods of cause-and-effect relationships, and the graphical method. The information base was made up of scientific and analytical reports, official websites of research objects, and data from the Federal State Statistics Service. 


\section{Results and discussion}

Development institutions provide support through the financing of business projects, the provision of infrastructure support, as well as co-financing of $\mathrm{R} \& \mathrm{D}$. The main areas of support for business development institutions are projects that have a significant impact on the social and economic situation of the territories of Russia, including:

- projects that promote the creation of innovative high-tech products, competitive production facilities using innovative technologies;

- projects that comply with the import substitution policy;

- projects in the field of nanotechnology;

- support and development of small innovative enterprises.

The key tasks and directions of the main development institutions are presented in Fig. 1.

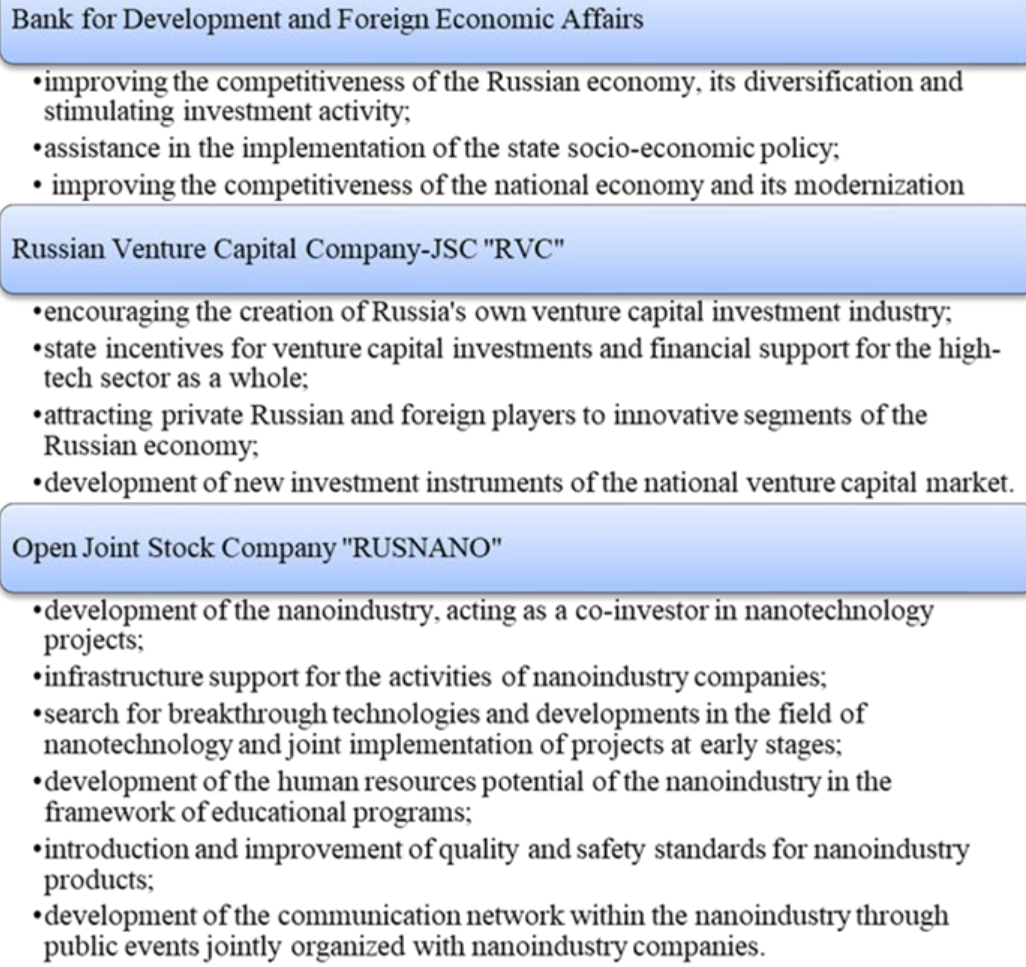

Fig. 1. Key tasks and directions of Russian development institutions (summarized by the author on the basis of data from official websites). 
Currently, there are no requirements for the transparency of the organization of development institutions, which does not allow us to assess the effectiveness of their activities. The special legal status and low transparency of development institutions against the background of state funding are a prerequisite for inefficient spending of funds.

Budget expenditures on innovative development institutions in 2006-2020 exceeded 965 billion rubles (Table 1), and 270 billion rubles are also planned for the next 3 years.

Table 1. Financing of some innovative development institutions in 2006-2023, RUB billion (calculations based on the data of the Federal Treasury).

\begin{tabular}{|c|c|c|c|c|c|c|}
\hline $\begin{array}{c}\text { Development } \\
\text { institutions }\end{array}$ & $\begin{array}{c}\text { Year of } \\
\text { creation }\end{array}$ & $\begin{array}{c}2006- \\
2020\end{array}$ & 2021 & 2022 & 2023 & $\begin{array}{c}2021- \\
2023\end{array}$ \\
\hline SKOLKOVO & 2010 & 10 & 12 & 13 & 13 & 39 \\
\hline RFBR & 1993 & 29 & 21 & 21 & 21 & 64 \\
\hline Rusnano & 2007 & 65 & 0 & 0 & 2 & 2 \\
\hline RDIF & 2011 & 0 & 0 & 0 & 0 & 0 \\
\hline RDIF & 1996 & 0 & 2 & 1 & 1 & 5 \\
\hline VEB & 2007 & 384 & 15 & 19 & 17 & 50 \\
\hline $\begin{array}{c}\text { all development } \\
\text { institutes (44 } \\
\text { organizations) }\end{array}$ & & 798 & 220 & 193 & 242 & 655 \\
\hline
\end{tabular}

However, the level of innovation has not increased in recent years. The share of innovative products is $6 \%$ instead of the planned $25 \%$ in 2020. From 1990 to 2020, the number of researchers decreased by more than 3 times (Fig. 2).

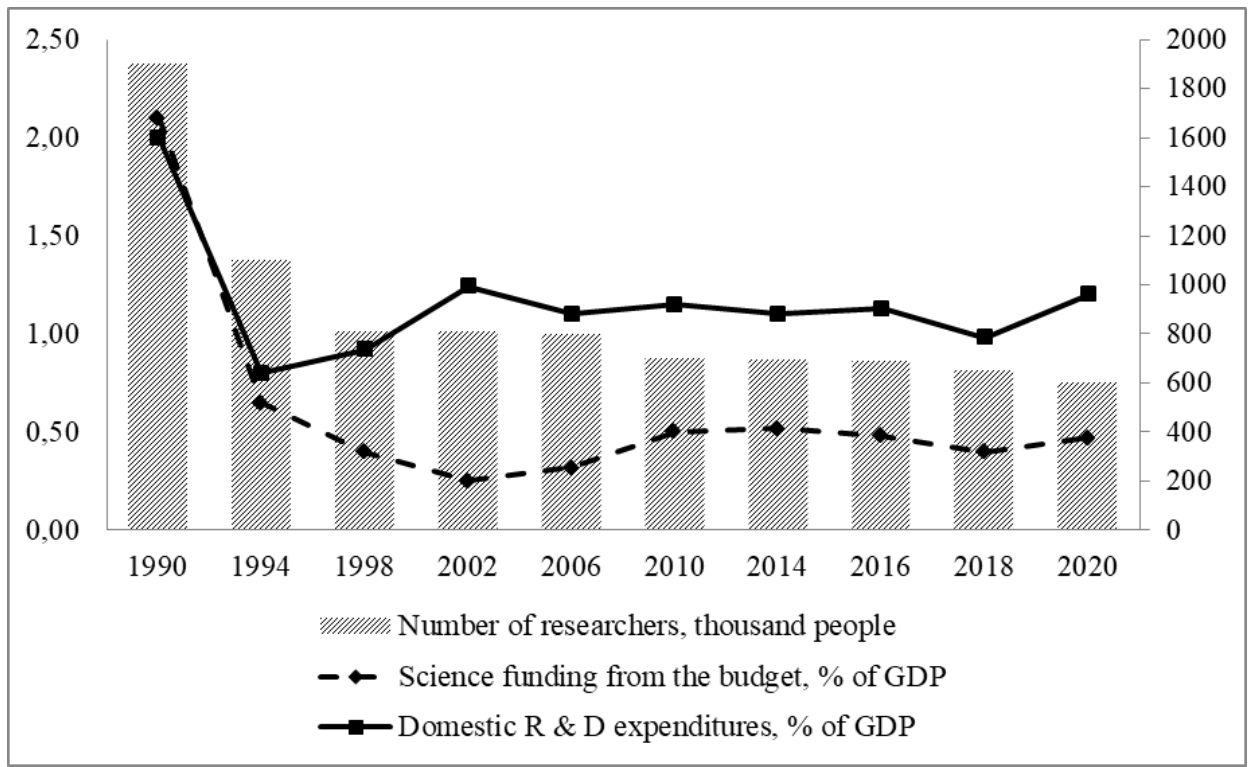

Fig. 2. Dynamics of reductions in spending on science and the number of researchers in Russia (constructed by the author on the basis of data [11]).

The financing of science from the budget as a percentage of GDP has almost halved, and domestic R \& D expenditures have more than doubled.

The report of the Financial Research Institute notes the following examples of inefficient and inappropriate spending of funds: 
- placement of money on deposits, which is due to the lack of promising projects in the market conditions with high quality teams, as well as significant bureaucratic pressure and the risk of prosecution of the heads of development institutions for unsuccessful investments;

- exporting money instead of importing technology;

- unreasonably high salaries of top managers, etc.

The main problem is the formation of a system of criteria and key performance indicators for supporting development institutions, depending on priorities, and the identification of the strengths and weaknesses of Russian development institutions in comparison with similar structures operating in the world's leading innovation ecosystems, as well as improving their effectiveness and contribution to the Russian economy.

The low efficiency of the institutions is also recognized in the government, and therefore a decision was made to reform them. As a result of the audit of 40 federal institutions, eight were decided to be liquidated, and the rest were enlarged. Due to the consolidation, the institutions will be strengthened financially, they will expand the range of opportunities and eliminate parallel budgets. In particular, Russian Venture Company will come under the wing of the Russian Direct Investment Fund, which proved itself with the Covid-19 vaccine. The Russian Science Foundation will be subordinated to the Russian Foundation for Basic Research. Innovative development institutions (in particular, Rusnano, the Bortnik Foundation, etc.) will be transferred to the management of Bank for Development and Foreign Economic Affairs. Ultimately, the goal of the transformation is to launch a new investment cycle.

To assess the effectiveness of innovation development institutions in the Russian context, we propose a system of key performance indicators:

1. Key indicators of development institutions in general:

- the volume of GDP or GRP increase related to investment;

- the amount of increase in tax revenues to the budgets of all levels;

- the growth of added value and the volume of innovative products;

- the number of high-performance jobs created and upgraded;

- the share of products of high-tech and knowledge-intensive sectors of the economy in the gross domestic product;

- increase in labor productivity.

2. Key indicators of innovation activity development:

- number of innovation-active organizations;

- organizations that perform research and development;

- intellectual resources;

- internal research and development costs;

- costs of technological innovation;

- the volume of innovative products shipped;

- the number of advanced manufacturing technologies used.

It is also necessary to remember that one of the key factors for the success of any institution is highly qualified personnel. And the basis for evaluating the effectiveness of the development institute should be supplemented with the principle of sustainable development, which implies evaluating any project for creating value for future generations.

\section{Conclusions}

It is necessary to develop a set of measures aimed at solving problems in the field of innovative development institutions and ensuring the effectiveness of their functioning in modern conditions. Decisions should include the following areas of activity: 
- development of regulatory documents for the purpose of monitoring and controlling the activities of development institutions and a clear definition of their legal status;

- modernization of business models of development institutions that correspond to world practice;

- reorganization of the organizational and legal forms of development institutions;

- adjustment of mechanisms for bringing funds to recipients who are directly involved in the creation of innovative products;

- conducting an assessment of the feasibility and effectiveness of investments in foreign funds;

- development of measures to improve the efficiency of management of development institutions ' funds;

- development of requirements for transparency and openness of the activities of development institutions, and general principles of their functioning, allowing to assess and monitor the effectiveness of their functioning both for the state and for society as a whole;

- development and approval of a system of key performance indicators of development institutions by the state.

\section{References}

1. On approval of the list of innovative development institutions [Electronic resource] Order of the Government of the Russian Federation No. 241-r of February 5, 2021 URL: docs.cntd.ru/document/573548055 (last accessed: 25.04.2021)

2. I. N. Rykova, Evaluation of the effectiveness of Russian and foreign development institutions, Moscow: Scientific Research Financial Institute, 204 (2016)

3. T. V. Tischenko. Analysis of the activity of Russian development institutions in innovations stimulation, Creative economy 13 (1), 105-114 (2019) DOI: 10.18334/ce.13.1.39731

4. S. S. Kudryavtseva, F. F. Galimulina, I. A.Zaraychenko, N. V. Barsegyan, Modeling The Management System Of Open Innovation In The Transition To E-Economy, Modern Journal of Language Teaching Methods, 8 (10), 163-171 (2018) DOI: $10.26655 / \mathrm{mjltm} .2018 .10 .1$

5. S. S. Kudryavtseva, A. I. Shinkevich, G. R. Garipova, A. V. Pavlova, A. D. Chudnovskiy, A. N. Nikolayeva, F. X. Doronina, I. I. Ishmuradova, Econometric methods for evaluating of open national innovative systems, International Journal of Economics and Financial Issues, 6(2), 640-645 (2016)

6. M. V. Shinkevich, Ch. A. Misbakhova, S. A. Bashkirtseva, T. A. Fedorova, O. V. Martynova, A. L. Beloborodova. Institutional factors of micro, mezzo and macro systems' innovative development, Journal of Advanced Research in Law and Economics, $\quad \mathbf{8} \quad$ (1), $229-236 \quad$ (2017) URL: journals.aserspublishing.eu/jarle/article/view/1149 (last accessed: 25.03.2021)

7. I. V. Milkina, Analysis of development institutions in the system of innovation support in the regions and municipalities of Russia, The science. Innovation. Education, 11 (2), 61-84 (2016) ISSN: 1996-9953, eISSN: 2658-5804

8. L. Kostygova, E. Sidorova, N. Vikhrova, Modern clusters and assessment of their innovative development, Entrepreneurship and Sustainability, 7(1), 603-614 (2019) DOI: 10.9770/jesi.2019.7.1(42)

9. A. Y. Anisimov, Yu. Yu. Kostyukhin, O. O. Skryabin, A. V. Zhaglovskaya, I. V. Androsova, National innovation system as a model of economic development, International journal of advanced biotechnology and research, 8, 2075-2082 (2017) ISSN: 0976-2612, eISSN: 2278-599X 
10. E. Sidorova, The main factors and conditions determining the feasibility of production of high-tech products based on the potential of applied research organizations, International Multidisciplinary Scientific GeoConference Surveying Geology and Mining Ecology Management, 19 (5.3), 841-847 (2019) DOI: $10.5593 /$ sgem $2019 / 5.3 / \mathrm{S} 21.106$

11. Federal State Statistics Service 2021 Official site URL: www.gks.ru (last accessed: 25.04.2021) 